OPEN ACCESS

Vol. 7, No. 2, Oktober, 2019

Page. $44-96$

DOI: https://doi.org/10.21107/jaffa.v7i2.6423
JOURNAL OF AUDITING, FINANCE, AND FORENSIC ACCOUNTING (JAFFA)

E-ISSN: 2461-0607 ISSN: 2339-2886

http://jaffa.trunojoyo.ac.id/jaffa

\title{
PREDICTION OF FINANCIAL DISTRESS IN MANUFACTURING COMPANY: A COMPARATIVE ANALYSIS OF SPRINGATE MODEL AND FULMER MODEL
}

Raid Ayasy Shalih, Fariyana Kusumawati

Accounting Department, Faculty of Economics and Business, University of Trunojoyo Madura

\section{Article Info:}

Received: 23 Agustus 2019

in revised form: 24 September 2019

Accepted: 08 Oktober 2019

Available Online: 13 Januari 2020

\section{Keywords:}

Financial Distress, Springate Model, Fulmer Model

Corresponding Author:

Email: raiconayas@yahoo.com

\begin{abstract}
This research aims to analyze the differences in financial distress predictions between the Springate model and the Fulmer model. The method used in this research is quantitative. The type of data used in this research is secondary data in the form BEI of company financial statements for 2014-2016. The data analysis technique uses the One Way ANOVA test. The results showed that there are significant differences between the Springate model and the Fulmer model in predicting financial distress in manufacturing companies listed on the Indonesia stock exchange during 2014-2016. The most relevant model in predicting financial distress in this study is the Springate model.
\end{abstract}

Abstrak; Penelitian ini bertujuan untuk menganalisis financial distress dengan perbandingan model Springate dan model Fulmer. Penelitian ini menggunakan metode kuantitatif dengan data sekunder perusahaan manufaktur di BEI pada tahun 2014-2016. Penelitian ini menggunakan One-Way ANOVA test. Hasil penelitian menunjukkan bahwa adanya perbedaan yang signifikan antara model Springate dan Fulmer dalam memprediksi financial distress di perusahaan manufaktur. Hasil analisis menunjukkan bahwa Model Springate lebih relevan dalam memprediksi financial distress. 


\section{INTRODUCTION}

The economic development requires companies to continue developing innovation, improving performance, and expanding their businesses in order to survive in the competition. The level of company skill is highly determined by its performance itself (Sumbodo, 2010). The company's performance can be measured by the profit generated, when the company can generate high profits, it is possible that it has a high cash flow as well so that it can operate smoothly and avoid financial distress or threat to its business continuity (Muflihah, 2017). The phenomenon of financial distress occurs if the companies are unable to survive because they make mistake in capturing the market opportunities or in strategy. As a result, the companies always experience a decrease in profit or loss, which eventually causes bankrupt. One example is the case of General Motor Indonesia (GMI) that was officially closed or declared bankrupt in 2015. GMI suffered a loss of USD 4 million every month since it began operating in 2013, bringing the total losses suffered by GMI until 2015 to reach USD 200 million (sindonews.com).

Financial statements can measure the prediction of company bankruptcy. The companies make financial statements and disclosures with the aim to provide useful information for decision making in investment and funding. Prediction of the company's survival is crucial for the management and company owners to anticipate the occurrence of financial distress that leads to bankruptcy measured through the analysis of financial statements in the form of financial ratios issued by the company (Sumbodo, 2010).

Analysis of the bankruptcy symptoms is necessary in order to anticipate bankruptcy in the future, therefore the researcher will examine the financial distress in the following year which is 2014-2016 in order to find out which companies that will experience distress and healthy companies (Adriana, 2012).

In predicting financial distress, the company needs a prediction tool or model to detect bankruptcy. The financial distress model needs to be developed to find out the state of the company's financial distress early, so that the company can take actions to anticipate conditions that lead to bankruptcy. Financial distress occurs before bankruptcy. Financial distress condition can be identified earlier by using a certain model (Rahayu, 2016).

Springate (1978) used 19 popular financial ratios in his research. However, after retesting, he finally chose 4 ratios used in determining the criteria for companies that were included in the category of healthy companies or potentially bankrupt companies (Springate, 1978). Springate model in predicting bankruptcy potential has an accuracy rate of $92.5 \%$.

Another model is Fulmer model which used the step-wise multiple discriminant analysis method to evaluate 40 financial ratios applied to a sample of 60 companies. According to Fulmer, 30 companies had failed and the other 30 companies had succeeded. Fulmer model reports an accuracy rate of $98 \%$ to the company one year before it fails and an accuracy rate of $81 \%$ more than one year before bankruptcy, there are 9 ratios in Fulmer model.

Some previous research showed different results in analyzing the prediction of bankruptcy within a company, including a research conducted by Lukman \& Ahmar (2015) which stated that there were differences in the prediction results of financial distress determination. Calculations using the Fulmer h-score model showed that most mining companies in 2011-2014 indicated bankruptcy of $26.35 \%$ and $73.65 \%$ of the companies were predicted as healthy company.

Research conducted by Rahmadani (2015) showed the results of the processing and analysis of financial data in 2011-2015 by using three bankruptcy prediction models. Here, Fulmer and Springate predicted PT. Bank Ekonomi Raharja went bankrupt during this period, while Altman method predicted PT. Bank Ekonomi Raharja to be in "gray area" category. In addition, the level of conformity between bankruptcy prediction and auditor opinion was only $20 \%$, and this was in accordance with conditions that had been delisted from the stock exchange.

Ambarwati et al (2016) in their research concluded that there were differences in the determination of financial distress predictions. Altman Z-Score in 2013 and 2015 predicted bankruptcy while in 2014 predicted in the gray area. Meanwhile, Springate 
model in 2013-2015 predicted bankruptcy since it was below the company's health value criteria. According to Zmijewski in 2013-2015, it was healthy with negative results. According to Fulmer in 2013 and 2014, it experienced a healthy condition but in 2015 it experienced a bankrupt condition.

Research done by Fanny (2017) stated that there were differences in Altman, Springate, and Zmijewski prediction models in predicting financial distress conditions in plantation companies listed on the Indonesia Stock Exchange during 2012-2014 period. The results of subsequent research found that Zmijewski model had an accuracy rate of $82 \%$ while Altman model and Springate model had an accuracy rate of $55 \%$ and $45 \%$, respectively.

Research conducted by Priambodo (2017) concluded that there were significant differences between Altman, Springate, Grover, and Zmijewski models in predicting financial distress, and the highest level of accuracy was achieved by Springate model with an accuracy rate of $84.21 \%$.

Research performed by Kusumaningtyas (2017) revealed that each model, which were Zmijewski, Springate, and Fulmer, obtained the same or different results regarding the prediction of an unhealthy company in a financial statement at a certain period. In general, the samples were 17 companies and Zmijewski model was able to predict $29.41 \%$ of the occurrence of unhealthy companies, while Springate model and Fulmer model were able to predict of unhealthy companies by $41.18 \%$ and $17.65 \%$, respectively.

Based on several previous research, Springate model and Fulmer model were the strongest models in predicting financial distress from various financial distress prediction models such as Atlman, CA-score, Zmijewski, and others whose levels of accuracy were lower. This statement was also mentioned by Kasingilam and Ramasundaram (2012) who said that Springate model and Fulmer H-score model could be used in predicting company bankruptcy by reporting higher levels of accuracy than other models such as Altman, CA-score, Zmijewski, and others whose levels of accuracy were lower. Thus, this research aims to conduct a comparative analysis of Springate model and Fulmer model of financial distress predictions in manufacturing companies on Indonesia Stock Exchange (IDX).

\section{LITERATURE REVIEW AND HYPOTHESES DEVELOPMENT}

\section{Teori Signal}

Signaling theory is a theory that reveals that the company gives signals to the users of financial statements. The most awaited information from external parties is in the form of good news. This theory states that good quality companies will give signals intentionally to the market, so the market is expected to be able to distinguish the company quality (Hartono, 2005: 38).

According to Hanafi (2014) financial distress can be described from two extreme points of short-term liquidity problems to insolvable. Indicators of financial difficulties can be seen from the analysis of cash flow, analysis of company strategies, and company's financial statements. Financial distress can be interpreted as the emergence of early signals or symptoms of bankruptcy on the decline in financial conditions experienced by a company, or conditions that occur before bankruptcy or liquidation. If a company cannot maintain its survival, it will go bankrupt. Bankruptcy can be seen from the flow approach and stock approach (Hanafi, 2014: 638).

\section{Prediction of Financial Distress}

Springate (1978) carried out a research to find a model that could be used in predicting the potential (indication) of bankruptcy. He used 19 popular financial ratios which could be used to predict financial distress. He finally found 4 ratios that could be used in predicting the potential (indication) of bankruptcy which had an accuracy of up to $92.5 \%$. He classified a company as bankrupt if it had a score of less than 0.862 ( $\mathrm{S}<$ 0.862 ). Conversely, if the $\mathrm{S}$-Score calculation results exceeded or equal to 0.862 ( $\mathrm{S} \geq$ 0.862), the company was classified as a financially healthy company. Fulmer 1984 used 
the step-wise multiple discriminant analysis method. This model reported an accuracy rate of $98 \%$ to the company one year before it failed and an accuracy rate of $81 \%$ more than one year before bankruptcy. This model describes the following formula:

\section{Differences in the Results of Prediction of Financial Distress between Springate Model and Fulmer Model}

Springate Model and Fulmer Model are models that can predict company bankruptcy in the future and can serve as an early warning for management to reevaluate the company's financial performance when bankruptcy is identified. This test works to determine whether there are statistical differences between Springate model and Fulmer model so that it finds the best prediction model between the two models in predicting the company's level of financial difficulty. It is related to signaling theory, which is an action taken by the company to give a signal (information) to investors about how management views the company's prospects. The information released by large companies affects the investment decisions of the parties outside the company (Brigham and Hauston, 2001).

Signaling theory also can help companies (agents), owners (principals), and external parties to reduce information asymmetry by producing the quality or integrity of financial statement information. In ensuring that the interested parties believe the reliability of financial information submitted by the company (agent), the company needs to get an opinion from other parties who are free to give opinions about financial statements. Management must be open or transparent in presenting the company's financial statements. In the financial statements, it will be known whether the company is in good health or experiences financial distress (Jama'an, 2008).

\section{RESEARCH METHODOLOGY}

The method used in this research was quantitative. The type of data used in this research was secondary data, namely financial statements in the form of balance sheets and income statements of each company from 2014 to 2016 in manufacturing industry companies listed on the Indonesia Stock Exchange. The hypothesis in this research was tested using One Way ANOVA. Ghozali (2013) explains the terms of testing the assumptions of normality and homogeneity before ANOVA testing.

\section{FINDINGS AND DISCUSSION}

\section{Results of Normality Test}

\section{Figure 1. Results of Normality Test}

\begin{tabular}{lllllllll}
\hline \multirow{2}{*}{ MODEL } & \multicolumn{3}{c}{ Kolmogorov-Smirnov } & \multicolumn{3}{c}{ Shapiro-Wilk } \\
\cline { 2 - 9 } & & Statistic & df & Sig & Statistic & df & Sig \\
\hline \multirow{2}{*}{ Prediksi } & SPRINGATE & 0.155 & 18 & 0.200 & 0.944 & 18 & 0.334 \\
\cline { 2 - 9 } & FULMER & 0.252 & 18 & 0.004 & 0.838 & 18 & 0.006 \\
\hline
\end{tabular}

Based on Figure 1 above, the results of normality testing on each financial distress prediction model on manufacturing companies listed on the Indonesia Stock Exchange during the 2014-2016 period showed that the significance results for Springate model had a value of 0.200 which meant $0.200>0.05$, so this model had normally distributed data in predicting financial distress. Fulmer model had a value of 0.004 which meant $0.004<0.05$, so this model had abnormally distributed data in predicting financial distress. 


\section{Results of Homogeneity Test}

Figure 2. Results of Homogeneity Test

\begin{tabular}{cccc}
\hline Levene Statistic & df1 & df2 & Sig. \\
\hline 4.178 & 1 & 34 & 0.049 \\
\hline
\end{tabular}

Figure 2 above showed the significance value of 0.05. Although the assumption of homogeneity was not fulfilled, Ghozali (2013) stated that ANOVA could still be used because ANOVA was robust for small and moderate deviations from homogeneity of variance.

Figure 3. Results of one way ANOVA Test

\begin{tabular}{cccccc} 
& $\begin{array}{c}\text { Sum of } \\
\text { Squares }\end{array}$ & df & $\begin{array}{c}\text { Mean } \\
\text { Aquare }\end{array}$ & F & Sig. \\
\hline Between Groups & 41.950 & 1 & 41.950 & 28.185 & 0,000 \\
Within Groups & 50.606 & 34 & 1.488 & & \\
$\quad$ Total & 92.556 & 35 & & & \\
\hline
\end{tabular}

Based on the results of one way ANOVA test, the significance value produced a value of $0,000<0.05$, thus $\mathrm{Ha}$ was accepted and it could be said that there were differences in financial distress predictions between Springate model and Fulmer model. The results of the research were in the form of a detailed explanation and comparison of the status set by Springate model and Fulmer model with a sample of 18 manufacturing companies during 2014-2016, as follows:

Figure 4. Results of prediction of Springate model and Fulmer model in 2014

\begin{tabular}{|c|c|c|c|c|c|c|}
\hline \multicolumn{3}{|c|}{$\begin{array}{l}\text { Cut off Springate }>0,862=\text { Sehat } \\
\text { Cut off Springate }<0,862=\text { Distress }\end{array}$} & & \multicolumn{3}{|c|}{$\begin{array}{l}\text { Cut off Fulmer } \mathrm{H}>0=\text { Sehat } \\
\text { Cut off Fulmer } \mathrm{H}<0=\text { Distress }\end{array}$} \\
\hline \multirow{2}{*}{ NO } & \multirow{2}{*}{ PERUSAHAAN } & \multicolumn{2}{|c|}{ SPRINGATE } & \multicolumn{2}{|c|}{ FULMER } & \multirow{2}{*}{ KET } \\
\hline & & S-SCORE & KRITERIA & H-SCORE & KRITERIA & \\
\hline 1 & AKPI & 0,533269715 & DISTRESS & 2,932933072 & SEHAT & BEDA \\
\hline 2 & ALDO & 0,729806106 & DISTRESS & 2,493240055 & SEHAT & BEDA \\
\hline 3 & ALKA & 2,255439256 & SEHAT & 2,106777239 & SEHAT & TBEDA \\
\hline 4 & APLI & 1,193419645 & SEHAT & 3,671519267 & SEHAT & TBEDA \\
\hline 5 & BUDI & 0,471249134 & DISTRESS & 2,550444413 & SEHAT & BEDA \\
\hline 6 & CEKA & 1,609679446 & SEHAT & 3,719083266 & SEHAT & TBEDA \\
\hline 7 & INAI & 0,625120024 & DISTRESS & 2,196176699 & SEHAT & BEDA \\
\hline 8 & KBLM & 0,773235042 & DISTRESS & 2,706802841 & SEHAT & BEDA \\
\hline 9 & $\mathrm{KICl}$ & 1,742809939 & SEHAT & 9,142930972 & SEHAT & TBEDA \\
\hline 10 & LMPI & 0,3832936 & DISTRESS & 1,162481653 & SEHAT & BEDA \\
\hline 11 & LMSH & 2,009831663 & SEHAT & 8,57802903 & SEHAT & TBEDA \\
\hline 12 & PYF & 0,377581042 & DISTRESS & 772829392 & SEHAT & BEDA \\
\hline 13 & RICY & 0,666803255 & DISTRESS & 2,536586486 & SEHAT & BEDA \\
\hline 14 & SKLT & 1,219725821 & SEHAT & 2,50192899 & SEHAT & TBEDA \\
\hline 15 & SRSN & 1,329652949 & SEHAT & 3,655758768 & SEHAT & TBEDA \\
\hline 16 & TIRT & 0,665523724 & DISTRESS & 1,232178221 & SEHAT & BEDA \\
\hline 17 & TRIS & 1,411175973 & SEHAT & 3,065680333 & SEHAT & TBEDA \\
\hline 18 & UNIT & $-0,127533747$ & DISTRESS & 1,789340995 & SEHAT & BEDA \\
\hline
\end{tabular}

Based on Figure 4 it could be concluded that from 2014 the results of differences in the determination of bankruptcy status using Springate s-score model and Fulmer hscore model showed that there were 10 different companies or $55.55 \%$ difference from 54 research samples. Furthermore, the results of the similarity in the determination of the bankruptcy status in 2014 using Springate s-score model and Fulmer h-score model contained 8 same companies or $44.45 \%$ of 54 research samples. 
Figure 5. Results of prediction of Springate model and Fulmer model in 2015

\begin{tabular}{|c|c|c|c|c|c|c|}
\hline \multicolumn{3}{|c|}{$\begin{array}{l}\text { Cut off Springate }>0,862=\text { Sehat } \\
\text { Cut off Springate }<0,862=\text { Distress }\end{array}$} & \multicolumn{3}{|c|}{$\begin{array}{l}\text { Cut off Fulmer } \mathrm{H}>0=\text { Sehat } \\
\text { Cut off Fulmer } \mathrm{H}<0=\text { Distress }\end{array}$} & \multirow{3}{*}{ KET } \\
\hline \multirow{2}{*}{ NO } & \multirow{2}{*}{ PERUSAHAAN } & \multicolumn{2}{|c|}{ SPRINGATE } & \multicolumn{2}{|c|}{ FULMER } & \\
\hline & & S-SCORE & KRITERIA & H-SCORE & KRITERIA & \\
\hline 1 & AKPI & 0,37938251 & DISTRESS & 2,333781068 & SEHAT & BEDA \\
\hline 2 & ALDO & 1,15539113 & SEHAT & 2,895026514 & SEHAT & TBEDA \\
\hline 3 & ALKA & 2,09207668 & SEHAT & 1,193609203 & SEHAT & TBEDA \\
\hline 4 & APLI & 0,42434566 & DISTRESS & 2,438047786 & SEHAT & BEDA \\
\hline 5 & BUDI & 0,36381133 & DISTRESS & 2,59522185 & SEHAT & BEDA \\
\hline 6 & CEKA & 1,64998416 & SEHAT & 4,405139949 & SEHAT & TBEDA \\
\hline 7 & INAI & 0,59034499 & DISTRESS & 2,469900225 & SEHAT & BEDA \\
\hline 8 & KBLM & 0,76452464 & DISTRESS & 2,840761423 & SEHAT & BEDA \\
\hline 9 & KICI & 0,94302978 & SEHAT & 1,141299271 & SEHAT & TBEDA \\
\hline 10 & LMPI & 0,38625901 & DISTRESS & 1,187295573 & SEHAT & BEDA \\
\hline 11 & LMSH & 1,43881057 & SEHAT & 9,208071245 & SEHAT & TBEDA \\
\hline 12 & PYFA & 0,94767037 & SEHAT & 3,538557294 & SEHAT & TBEDA \\
\hline 13 & RICY & 0,56344977 & DISTRESS & 2,726097359 & SEHAT & BEDA \\
\hline 14 & SKLT & 1,16944697 & SEHAT & 2,708914789 & SEHAT & T BEDA \\
\hline 15 & SRSN & 1,29439077 & SEHAT & 2,997858364 & SEHAT & TBEDA \\
\hline 16 & TIRT & 0,50654048 & DISTRESS & 1,16848007 & SEHAT & BEDA \\
\hline 17 & TRIS & 1,37400555 & SEHAT & 3,412916422 & SEHAT & TBEDA \\
\hline 18 & UNIT & $-0,1040203$ & DISTRESS & 1,855253553 & SEHAT & BEDA \\
\hline
\end{tabular}

Based on Figure 5 it could be concluded that from 2015, the results of differences in the determination of bankruptcy status using Springate s-score model and Fulmer hscore model showed that there were 9 different companies or $50 \%$ difference from 54 research samples. Furthermore, the results of the similarity in the determination of the bankruptcy status in 2015 using Springate s-score model and Fulmer h-score model contained 9 same companies or $50 \%$ of 54 research samples.

Figure 6. Results of prediction of Springate model and Fulmer model in 2016

\begin{tabular}{|c|c|c|c|c|c|c|}
\hline \multicolumn{3}{|c|}{$\begin{array}{l}\text { Cut off Springate }>0,862=\text { Sehat } \\
\text { Cut off Springate }<0,862=\text { Distress }\end{array}$} & \multicolumn{3}{|c|}{$\begin{array}{l}\text { Cut off Fulmer } \mathrm{H}>0=\text { Sehat } \\
\text { Cut off Fulmer } \mathrm{H}<0=\text { Distress }\end{array}$} & \multirow{3}{*}{ KET } \\
\hline \multirow{2}{*}{ NO } & \multirow{2}{*}{ PERUSAHAAN } & \multicolumn{2}{|c|}{ SPRINGATE } & \multicolumn{2}{|c|}{ FULMER } & \\
\hline & & S-SCORE & KRITERIA & H-SCORE & KRITERIA & \\
\hline 1 & AKPI & 0,506288 & DISTRESS & 4,305925 & SEHAT & BEDA \\
\hline 2 & ALDO & 1,566347 & SEHAT & 2,511001 & SEHAT & TBEDA \\
\hline 3 & ALKA & 3,342013 & SEHAT & 2,078576 & SEHAT & TBEDA \\
\hline 4 & APLI & 1,276203 & SEHAT & 3,581159 & SEHAT & TBEDA \\
\hline 5 & BUDI & 0,397712 & DISTRESS & 2,693854 & SEHAT & BEDA \\
\hline 6 & CEKA & 2,577112 & SEHAT & 5,922911 & SEHAT & TBEDA \\
\hline 7 & INAI & 0,558586 & DISTRESS & 2,329552 & SEHAT & BEDA \\
\hline 8 & KBLM & 1,006445 & SEHAT & 10,84108 & SEHAT & TBEDA \\
\hline 9 & KICl & 0,798308 & DISTRESS & 0,954379 & SEHAT & BEDA \\
\hline 10 & LMPI & 0,317119 & DISTRESS & 1,402781 & SEHAT & BEDA \\
\hline 11 & LMSH & 1,138028 & SEHAT & 6,126028 & SEHAT & TBEDA \\
\hline 12 & PYFA & 1,050292 & SEHAT & 3,51985 & SEHAT & TBEDA \\
\hline 13 & RICY & 0,551228 & DISTRESS & 2,708567 & SEHAT & BEDA \\
\hline 14 & SKLT & 0,917806 & SEHAT & 2,297139 & SEHAT & TBEDA \\
\hline 15 & SRSN & 0,585161 & DISTRESS & 2,763219 & SEHAT & BEDA \\
\hline 16 & TIRT & 0,68088 & DISTRESS & 1,44175 & SEHAT & BEDA \\
\hline 17 & TRIS & 1,197502 & SEHAT & 2,74863 & SEHAT & TBEDA \\
\hline 18 & UNIT & $-0,03767$ & DISTRESS & 1,665659 & SEHAT & BEDA \\
\hline
\end{tabular}

Based on Figure 6 it could be concluded that from 2016 the results of the difference in the determination of bankruptcy status using Springate s-score model and Fulmer h-score model contained 9 different companies or $50 \%$ difference from 54 research samples. Furthermore, the results of the similarity in the determination of bankruptcy status in 2016 using Springate s-score model and Fulmer h-score model contained 9 same companies or $50 \%$ of 54 research samples. 
Figure 7. Average of Results of prediction of Springate model and Fulmer model in 2014-2016

\begin{tabular}{|c|c|c|c|c|c|c|}
\hline \multicolumn{4}{|c|}{$\begin{array}{c}\text { Cut off Springate }>0,862=\text { Sehat } \\
\text { Cut off Springate }<0,862=\text { Distress }\end{array}$} & \multicolumn{3}{|c|}{$\begin{array}{c}\text { Cut off Fulmer } \mathrm{H}>0=\text { Sehat } \\
\text { Cut off Fulmer } \mathrm{H}<0=\text { Distress }\end{array}$} \\
\hline \multirow[b]{2}{*}{ vo } & \multirow[b]{2}{*}{ PERUSAHAAN } & \multicolumn{2}{|c|}{ SPRINGATE } & \multicolumn{2}{|c|}{ FULMER } & \multirow{2}{*}{ KET } \\
\hline & & S-SCORE & KRITERIA & H-SCORE & KRITERIA & \\
\hline 1 & AKPI & 0,472980063 & Distress & 3,190879696 & Non Distress & BEDA \\
\hline 2 & ALDO & 1,150514826 & Non Distress & 2,633089139 & Non Distress & TBEDA \\
\hline 3 & ALKA & 2,563176346 & Non Distress & 1,792987463 & Non Distress & TBEDA \\
\hline 4 & APLI & 0,964656148 & Non Distress & 3,230242121 & Non Distress & TBEDA \\
\hline 5 & BUDI & 0,410924096 & Distress & 2,613173582 & Non Distress & BEDA \\
\hline 6 & CEKA & 1,945591885 & Non Distress & 4,682378156 & Non Distress & TBEDA \\
\hline 7 & INAI & 0,591350227 & Distress & 2,331876298 & Non Distress & BEDA \\
\hline 8 & KBLM & 0,848068235 & Distress & 5,462880029 & Non Distress & BEDA \\
\hline 9 & KICI & 1,161382462 & Non Distress & 3,746202951 & Non Distress & TBEDA \\
\hline 10 & LMPI & 0,362223956 & Distress & 1,250852679 & Non Distress & BEDA \\
\hline 11 & LMSH & 1,528890157 & Non Distress & 7,970709565 & Non Distress & TBEDA \\
\hline 12 & PYFA & 0,791847898 & Distress & 2,943745607 & Non Distress & BEDA \\
\hline 13 & RICY & 0,593826852 & Distress & 2,657083632 & Non Distress & BEDA \\
\hline 14 & SKLT & 1,10232642 & Non Distress & 2,502660983 & Non Distress & TBEDA \\
\hline 15 & SRSN & 1,069735024 & Non Distress & 3,138945394 & Non Distress & TBEDA \\
\hline 16 & TIRT & 0,617647903 & Distress & 1,280802755 & Non Distress & BEDA \\
\hline 17 & TRIS & 1,32756124 & Non Distress & 3,0757422 & Non Distress & TBEDA \\
\hline 18 & UNIT & $-0,089739838$ & Distress & 1,770084435 & Non Distress & BEDA \\
\hline
\end{tabular}

Based on Figure 7 it could be concluded that from 2014-2016 the results of the difference in the determination of bankruptcy status using Springate s-score model and Fulmer h-score model contained 9 different companies or $50 \%$ difference from 54 research samples. Furthermore, the results of the similarity in the determination of bankruptcy status in 2014-2016 using Springate s-score model and Fulmer h-score model contained 9 different companies or $50 \%$ of 54 research samples.

Figure 8. Results of Comparison of Bankruptcy Status for 2014-2016 Period

\begin{tabular}{clcc}
\hline Tahun & Prediksi & Springate & Fulmer \\
\hline \multirow{2}{*}{2014} & Distress & 10 & - \\
\cline { 2 - 4 } & Non Distress & 8 & 18 \\
\hline \multirow{2}{*}{2015} & Distress & 9 & - \\
\cline { 2 - 4 } & Non Distress & 9 & 18 \\
\hline \multirow{2}{*}{2016} & Distress & 9 & - \\
\cline { 2 - 4 } & Non Distress & 9 & 18 \\
\hline
\end{tabular}

Figure 8 showed the results that there were differences in bankruptcy status between Springate model and Fulmer model, and it could be seen from the number of companies experiencing distress and non-distress (healthy) of the two models. During 2014-2016, the differences in the bankruptcy status could be seen by comparing the two models in each research period.

This research was in line with the research by Ambarwati (2016), Lukman \& Ahmar (2015), and Rahmadani (2015). Research conducted by Ambarwati (2016) entitled "Financial distress dengan Metode Springate, Zmijewski, Fulmer, dan Altman ZScore pada PT Tunas Baru Lampung TBK di BEP” showed results that there were differences in financial distress predictions between Zmijewski, Springate, Fulmer, and Altman models. Research conducted by Lukman \& Ahmar (2015) entitled "Model Prediksi Kebangkrutan Fulmer H-Score dan Springate: Mana yang Lebih Kuat?” revealed results that there were differences in financial distress predictions between Fulmer model and Springate model. Research conducted by Rahmadani (2015) entitled "Analisis Kesesuaian Prediksi Kebangkrutan Model Altman Z-Score, Fulmer Dan Springate Terhadap Opini Auditor Pada Perusahaan Delisting tahun 2015" unveiled results that there were differences between Altman, Fulmer, and Springate models. During 2014-2016 by using Springate s-score model, the number of companies in a distress (unhealthy) condition and indicating bankruptcy was $51.85 \%$ and the number of healthy companies was $48.15 \%$ from observations of 54 research samples. Fulmer hscore model showed that $100 \%$ of the 54 companies were indicated as healthy companies.

Springate model and Fulmer model showed different results. This was caused by differences in financial ratios used by each model. In 2014-2016, it showed that the average score for Springate s-score model was 0.97 and 3.13 for Fulmer model This showed that the theory produced by each model was very distinctive in determining the company's bankruptcy status. In addition, there were also differences in measurement 
values that had been set by each model.

Springate Model used ratio analysis to measure the performance, leverage, and liquidity of a company as follows $\mathrm{S}=1.03 \mathrm{WCTA}+3.07$ ROTA + 0.66 EBITCL + 0.4 TATO. Springate model was measured by cut off, if Springate value was greater than 0.862 then the company was included in healthy company category and if Springate value was smaller than 0.862 , the company was included in unhealthy was included in or had the potential to go bankrupt. In contrast, Fulmer model used the following this formula $\mathrm{H}=5.528$ RETA +0.212 TATO + 0.073 ROCE + 1.270 CFTD - 0.120 DR + 2.335 CLTA + 0.575 LOG (FA) + 1.083 WCTA + 0.894 LOG ICR - 6,075. Fulmer model was measured by its analysis criteria, if $\mathrm{H}<0$ it was predicted that the company experienced bankruptcy or unhealthy company condition. If $\mathrm{H}>0$ it was predicted that the company was in a good or healthy condition.

This research results revealed that between Springate model and Fulmer model, the most relevant model in predicting financial distress was Springate model. As shown in table 4.10, Springate model could predict financial distress in companies during the research period, while Fulmer model was less accurate in predicting the financial distress.

This research was in line with the research of Priambodo's (2017) and Kusumaningtyas (2017). Research conducted by Priambodo (2017) entitled "Analisis Perbandingan Model Altman, Springate, Grover, dan Zmijewski Dalam Memprediksi Financial Distress (Studi Empiris Pada Perusahaan Sektor Pertambangan Yang Terdaftar Di Bursa Efek Indonesia Periode 2012-2015)" stated that the most relevant financial distress prediction model was Springate model. Research conducted by Kusumaningtyas (2017) entitled "Analisis Prediksi Kebangkrutan Dengan Menggunakan Model Zmijewski, Springate dan Fulmer Pada Perusahaan Ritel Di Bursa Efek Indonesia" stated that the most relevant financial distress prediction model was Springate model.

It is related to signaling theory which is an action taken by a company to give signals (information) to investors about how management views the company's prospects (Brigham and Hauston, 2001). Signaling theory suggests how companies should give signals to the users of financial statements (Wolk, 2001). The information is in the form of published corporate bond rank and is expected to be a signal of the financial condition of a particular company and illustrates the likelihood of the debts owned (Maria, 2006).

Signaling theory states that a good quality company will give signal intentionally to the market, so the market is expected to be able to distinguish the company quality. However if the company experiences small or large decline in the profit or cash flow, it can lead to doubt in investment since there will be financial distress in the company (Hartono, 2005: 38).

In ensuring that the interested parties believe the reliability of financial information submitted by the company (agent), the company needs to get an opinion from other parties who are free to give opinions about financial statements. Management must be open or transparent in presenting the company's financial statements. In the financial statements, it will be known whether the company is in good health or experiencing financial distress (Jama'an, 2008).

\section{CONCLUSION AND SUGGESTIONS}

Based on the research related to the differences between Springate model and Fulmer model in predicting financial distress in manufacturing companies listed on the Indonesia stock exchange during 2014-2016, it showed that there were significant differences between Springate model and Fulmer model in predicting financial distress in manufacturing companies listed on the Indonesia stock exchange during 2014-2016. The differences between Springate Model and Fulmer model were caused by differences in the financial ratios used by each model as well asdifferences in value measurement that had been set by each model. The most relevant model in predicting financial distress in this research was Springate model. There were several limitations in this research including the limited data with low profit margins. Future research can expand the number of samples/data to be used and consider other financial distress prediction models, such as Zmijewski, Altman, Grover, and others. 


\section{REFERENCES}

Adnan, Muhammad A dan Taufik, Muhammad I. 2005. Analisis Ketepatan Prediksi Metode Altman Terhadap Terjadinya Likuiditas Pada Lembaga Perbankan. Jurnal Ekonomi dan Auditing. Vol. 5. No 2 Desember.Yogyakarta: Fakultas Ekonomi Universitas Islam Indonesia

Adriana, A.N. dan Rusli. 2012. Analisis Prediksi Kebangkrutan Menggunakan Metode Springate Pada Perusahaan Foods And Beverages Yang Terdaftar Di Bursa Efek Indonesia Periode 2006-2010. Jurnal Repository. FE Universitas Riau.

Agusti, Chalendra P. 2013. Analisis Faktor yang Mempengaruhi Kemungkinan Terjadinya Financial Distress. Universitas Diponegoro.

Ambarwati, Umi et al. 2016. Financial Distress Dengan Metode Springate, Zmijewski, Fulmer Dan Altman Z-Score Pada Pt Tunas Baru Lampung Tbk Di Bei. Jurnal Fakultas Ekonomi Universitas Islam Batik Surakarta.

Bahri, Syaiful. 2016. Pengantar Akuntansi. Yogyakarta: CV. Andi Offset.

Bambang, Riyanto. 2008. Dasar-dasar Pembelanjaan Perusahaan. Yogyakarta: Penerbit GPFE.

Brigham, E. F. and Daves, P. R. (2003) Intermediate Financial Distress Management With Thomson One. United States of America: Cengage South-Western.

Brigham, Eugene dan Joel F Houston, 2001. Manajemen Keuangan II. Jakarta:Salemba Empat.

Emrinnaldi. 2007. Analisis Pengaruh Praktek Tata Kelola Perusahaan (Corporate Governance) Terhadap Kesulitan Keuangan Perusahaan (Financial Distress): Suatu Kajian Empiris. Jurnal Bisnis dan Akuntansi, Vol. 9, No. 1.

Fanny, Triesie A. 2017. Analisis Perbandingan Model Prediksi Financial Distress pada Sub Sektor Perkebunan. Jurnal Ilmu dan Riset Akuntansi.Vol. 6. No. 6. Juni 2017.

Fulmer, J. G. Jr., Moon, James E., Gavin, Thomas A., Erwin, Michael J. 1984. A Bankruptcy Classification Model For Small Firms. Journal of Commercial Bank Lending, 25-37.

Gendro,Wiyono. 2011. Merancang Penelitian Bisnis dengan Alat Analisis SPSS 17.0 \& Smart PLS 2.0. Yogyakarta: Percetakan STIM YKPM.

Ghozali, Imam. 2013. Aplikasi Analisis Multivariate dengan Program SPSS. Edisi Ketujuh. Semarang: Badan Penerbit Universitas Diponegoro.

Hanafi, Mamduh M. 2014. Manajemen Keuangan. Edisi 1. Yogyakarta :BPFE.

Hanafi, Mamduh M., dan Abdul Halim. 2016. Analisis Laporan Keuangan. UPP STIM YKPN, Yogyakarta.

Hartono. 2005. Hubungan Teori Signalling dengan Underpricing Saham Perdana di Bursa Efek Jakarta. Jurnal Bisnis dan Manajemen. 5 (1). hal. 35-50.

Jama'an. 2008. Pengaruh Mekanisme Corporate Governance dan Kualitas Kantor Akuntan Publik Terhadap Integritas Informasi Laporan Keuangan (Studi Pada Perusahaan Publik Di BEJ).Tesis Strata-2.Program Studi Magister Sains Akuntansi.Universitas Diponegoro, Semarang.

Kusumaningtyas, Dega. 2017. Analisis Prediksi Kebangkrutan Dengan Menggunakan Model Zmijewski, Springate Dan Fulmer Pada Perusahaan Ritel Di Bursa Efek Indonesia. Artikel Ilmiah: Sekolah Tinggi Ilmu Ekonomi Perbanas. Surabaya.

Lukman, M dan Ahmar, N. 2015. Model Prediksi Kebangkrutan Fullmer H-Score Dan Springate: Mana Yang Lebih Kuat?. Seminar Nasional Cendekiawan: 2015.

Peter dan Yoseph. (2011). Analisis Kebangkrutan Dengan Metode Z-Score Altman, 
Springate dan Zmijewski Pada PT. Indofood Sukses Makmur Tbk Periode 20052009. Jurusan Manajemen, Universitas Kristen Maranatha. Akurat Jurnal Ilmiah Akuntansi Nomor 04 Tahun ke-2 Januari-April 2011.

Priambodo, Dimas. 2017. Analisis Perbandingan Model Altman, Springate, Grover, Dan Zmijewski Dalam Memprediksi Financial distress (Studi Empiris Pada Perusahaan Sektor Pertambangan Yang Terdaftar Di Bursa Efek Indonesia Periode 2012-2015). Jurnal Akuntansi Fakultas Ekonomi Universitas Negeri Yogyakarta

R, K., \& G, R. 2012. Predicting Solvency of Non Banking Financial Institutions in India Using Fulmer and Springate Model. Journal of Services Research Vol. 2 No. 1.

Rahayu, Putri. 2016. Analisis Penggunaan Metode Springate (S-Score) Sebagai Prediktor Kebangkrutan (Studi pada Perusahaan Textile yang Terdaftar di Bursa Efek Indonesia pada Tahun 2011-2013). Jurnal Ekonomi dan Bisnis Universitas Muhammadiyah Surakarta.

Rahmadani, Anissa A. 2015. Analisis Kesesuaian Prediksi Kebangkrutan Model Altman Z-Score, Fulmer Dan Springate Terhadap Opini Auditor Pada Perusahaan Delisting tahun 2015. Jurnal Ekonomi dan Bisnis Islam: Vol. 1. No. 2

Restuti, Maria Immaculata. 2006. Pengaruh Pertumbuhan Perusahaan Terhadap Peringkat Obligasi Dan Yield Obligasi. Jurnal Akuntansi dan Keuangan, Volume 1 No 3, 2007.

Springate, Gordon L.V. 1978. Predicting The Possibility of Failure in a Canadian Firm. Unpublished Master Thesis. Simon Fraser University. January 1978.

Sumbodo, Joko. 2010. Perbandingan Model Diskriminan Dan Model Logit Untuk Memprediksi Financial Distress Perusahaan Manufaktur Di Bei. Universitas Sebelas Maret. Surakarta.

Sarwono, Jonathan. 2009. Memadu Pendekatan Kuantitatif dan Kualitatif: Mungkinkah?. Jurnal Ilmiah Manajemen bisnis. Vol 9, No. 2. Mei 2009: 119-132.

Wolk, et al 2001. Signaling, Agency Theory, Accounting Policy Choice. Accounting and Business Research. Vol. 18. No 69:47-56.

https://ekbis.sindonews.com/read/1085897/39/perusahaan-besar-bangkrut-diindonesia-1455640928 (Retrieved on July 20, 2018, at 20:00)

www.idx.co.id (Retrieved on July 17, 2018, at 19:00) 